\title{
Utilization of Integrative Technique for Partial Recovery of Proteases from Soil Microbes
}

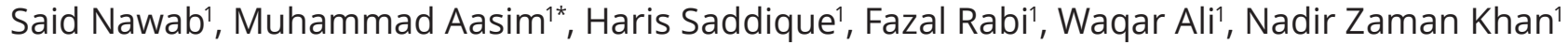 \\ 1 Department of Biotechnology, Faculty of Biological Sciences, University of Malakand, \\ Lower Dir, 18800, Khyber Pakhtunkhwa, Pakistan \\ * Corresponding author, e-mail: draasim@uom.edu.pk
}

Received: 05 June 2018, Accepted: 03 October 2018, Published online: 30 November 2018

\begin{abstract}
Aqueous two-phase system (ATPS) is an efficient, cost effective, fast, simple and ecofriendly method for the recovery of biomolecules. In the present study, an ATPS composed of polyethylene glycol and ammonium sulphate $\left(\mathrm{NH}_{4}\right)_{2} \mathrm{SO}_{4}$ was used for the partial purification of proteases from microbial source. The effects of different parameters such as molecular weight of PEG (4000, 6000 and 10000), concentration of PEG $(15,17.5$ and $20 \%)$ and concentration of $\left(\mathrm{NH}_{4}\right)_{2} \mathrm{SO}_{4}(7.5,8.3,9.1$ and $9.9 \%)$ on the partitioning behavior of proteases at room temperature were investigated. Generally, increasing the concentration of PEG and $\left(\mathrm{NH}_{4}\right)_{2} \mathrm{SO}_{4}$ moved the protease to the top i.e., polymer-rich phase. Increasing the molecular weight of PEG from 4000 to 10000 the partition coefficient decreased subsequently. The highest partition coefficient i.e., 3.32 and maximum activity i.e., 16.06 soxhlet unit was found in an optimum system composed of $20 \%$ PEG 4000 and $9.9 \%\left(\mathrm{NH}_{4}\right)_{2} \mathrm{SO}_{4}$.
\end{abstract}

Keywords

proteases, aqueous two-phase system, partitioning, partition coefficient, polyethylene glycol (PEG), ammonium sulphate

\section{Introduction}

Proteases are a class of enzymes, which break down and hydrolyse peptide bond of proteins into polypeptide or into free amino acids [1] and constitute $60 \%$ of the total worldwide enzyme market. The proteases have valuable industrial and biotechnological application [2]. Several industrially important proteases are generally produced by plants such as ficin, papain and bromelain [3]. Animals are also good source of some important proteases such as trypsin, chymotrypsin, pepsin and renin [4]. Due to increased demand of industrial proteases the animal and plant sources are not enough to meet the world demand so the proteases production by microbial fermentation has been increased dramatically. Therefore, microorganism are regarded as an important source of protease enzymes because they can produce large quantities of enzymes in a short period of time using different established fermentation techniques. They can be easily genetically modified than animals and plants. In addition, the proteins they produce are more stable than plants and animals sources [5]. Worldwide, microorganisms are responsible for two-third production of the commercial proteases [6]. Proteases are commercially exploited in detergents, leather industry, food industry, pharmaceutical industry and bioremediation processes. Bacillus species of bacteria are the main producer of protease.

Fermentation is the main technology used for the production of a wide range of biomolecules including proteases. Purification of biomolecules from the fermentation broth is challenging task. The whole process from production to purification is the combination of several sub-processes. Upstream processing deals with the production of biomolecules and in the downstream processing target molecules are recovered and purified [7]. Purification takes more than $70 \%$ of the downstream processing costs $[8,9]$. The routine downstream techniques such as chromatography, precipitation, centrifugation and electrophoresis have been widely used for the separation and purification of enzymes. In downstream processing a large number of unit operation are involved in which some quantity of the target molecules is lost [10]. However, these technique are expensive, providing low yields and are not suitable for large scale production. Therefore strategies are needed to develop an efficient, cost effective, fast, simple and eco-friendly downstream 
processing methods for recovery of biomolecules. Hence, integrative techniques such as aqueous two phase system (ATPS) are used as alternative for the separation of biomolecules where extraction, concentration and partial purification can be combined into one unit operation which reduces number of unit operations minimize the overall cost and product loss [11]. ATPS are formed when two immiscible polymer/polymer, polymer/salt, or salt/ salt are dissolved in aqueous solutions above their critical concentration [12]. Several researchers have studied the general properties of ATPS [13, 14] but the exact mechanism governing the partition of biomolecules is still not fully understood. However, the partition coefficient for the biomolecule in an ATPS is affected by different factors such as, van der Waals forces, hydrogen bonds, hydrophobic and ionic interactions between the biomolecule and the surrounding phases. Partitioning of proteins in ATPS can be influenced by the systematic variation of system compositions, including the type, concentration and molecular weight of the phase forming polymers, the concentration, $\mathrm{pH}$ and type of phase forming salt, the type and concentration of neutral salt and several other factors [15]. Both phases contain high water content (80-90\%) and thus provide an excellent and non-denaturing environment for cells, cell organelles and biological active substances [16]. The most frequently studied ATPS used is polymer/salt due to its low cost, low viscosity and minimum time required for the phase separation. ATPS of polymer-salt has wide range of applications in biotechnology and are mostly used as large and laboratory scale liquid extraction method [17]. ATPS has widely been used for the extraction and purification of biological material such as protein [18], enzymes [19], viruses [20], nucleic acids [21], antibodies [22], antibiotics [23], and cell organelles [24].

The aim of this study is to partially purify proteases from microbial sources using ATPS composed of polyethylene glycol (PEG) and ammonium sulphate salt. Different parameters such as molecular weight and concentration of the polymer, concentration of ammonium sulphate salt on protease partitioning were evaluated.

\section{Materials and Methods}

\subsection{Chemicals}

Tryptone, sodium chloride and yeast extract were purchased from Oxoid (Basingstoke, Hampshire, England). Polyethylene glycol (PEG-4000, 6000, 10000), Tris, Sodium dodecyl sulphate (SDS), Iso-propanol and methanol were obtained from Sigma-Aldrich (Steinheim,
Germany). Agar, Skim milk, Coomassie Brilliant Blue G-250, N,N,N,N, tetramethyl ethylene diamine (TEMED) were bought from AppliChem (Darmstadt, Germany). N, $\mathrm{N}$, Methylen-bis-acrylamide and acrylamide were purchased from Roth (Karlsruhe, Germany). Glycine was purchased from Phyto-technology Laboratories (Shawnee, KS, United States). Ammonium-per-sulphate, sodium hydroxide and calcium chloride were bought from Riedal-de Haen (Seezle, Germany). Acetic Acid was bought from LabScan analytical sciences (Thailand). Beta-mercaptoethanol and Ammonium sulfate were purchased from Merck (Darmstadt, Germany). Tris $\mathrm{HCl}$ was obtained from Bio Basic Inc. Markham (Onatario, Canada) and hydrochloric acid from Scharlau (Spain). Prestained protein ladder was bought from Thermoscientific page Ruler (Vilnius, Lithuania). A bench top centrifuge (Model 5804) was purchased from Eppendorf (Hamburg, Germany).

\subsection{Bacterial culturing, protease confirmation and preparation of bimodal curve}

Bacillus isolate was obtained from the soil sample of the northern areas of Khyber Pakhtunkhwa, Pakistan (identified through biochemical tests). The bacteria was cultured on a nutrient agar plates at $37{ }^{\circ} \mathrm{C}$ for $18-24 \mathrm{hrs}$. Luria-Bertani (LB) medium (yeast extract $0.5 \%$, sodium chloride $1 \%$, tryptone $1 \%$ ) was prepared according to Haddar et al. [25]. The media was autoclaved at $121{ }^{\circ} \mathrm{C}$ for 20 minutes in $500 \mathrm{~mL}$ Erlenmayer flask. A loop full of bacteria was inoculated to $100 \mathrm{~mL} \mathrm{LB}$ media in sterile environment and incubated at $37{ }^{\circ} \mathrm{C}$ for $48 \mathrm{hrs}$ in shaking incubator at $150 \mathrm{rpm}$; Cells were harvested at 14000 rpm for $15 \mathrm{~min}$ and discarded [26, 27] while supernatant was used as crude enzyme extract for further processing. Protease activity of the supernatant was confirmed by applying crude extract on skim milk agar plate using well diffusion method [28]. The bionodal curve of the aqueous two phase system was determined using the standard procedure of turbiometric titration [29].

\subsection{Aqueous two phase system formation}

Aqueous two phase systems were prepared by mixing the required quantities from the stock solution of PEG 4000, 6000, 10000 and Ammonium sulphate at room temperature. Final volume of the system was equal to $7 \mathrm{~mL}$ after the addition of crude enzyme extract. The contents were mixed thoroughly for two minutes. For complete phase separation each system was centrifuged at $4{ }^{\circ} \mathrm{C}$ at $2000 \mathrm{rpm}$ for two minute in density gradient 
centrifugation. After phase separation the sample was taken from the top and bottom phase to analyse the presence of enzyme.

The partition coefficient for protease $(K)$ was determined as the ratio of protease activity in the top phase $\left(A_{T}\right)$ to that in the bottom phase $\left(A_{B}\right)$ mentioned in Eq. (1).

$$
K=\frac{A_{T}}{A_{B}}
$$

\subsection{Milk clotting activity assay}

Milk clotting activity was determined according to the procedure described in the literature [30], which was based on the formation of first particles and expressed in the term of soxhlet units (SU). One soxhlet units is defined as the quantity of enzyme required to clot $1 \mathrm{~mL}$ of the substrates within $40 \mathrm{~min}$ at $35^{\circ} \mathrm{C}$. In order to perform the assay $1.0 \mathrm{~mL}$ milk solution (10\% powder skim milk and $0.01 \mathrm{M} \mathrm{CaCl}_{2}$ ) was preheated for 10 minutes in water bath at $35{ }^{\circ} \mathrm{C}$. Add $0.3 \mathrm{~mL}$ of sample from the top and bottom phase of each system and mixed thoroughly to start the reaction. To observe the clot formation the tube was rotated manually from the start time until the appearance of first particle in the milk. The clotting activity was determined in triplicate by using the following formula:

$U=\frac{M(\mathrm{~mL})}{E(\mathrm{~mL})} \times \frac{35^{\circ}}{t} \times \frac{2400}{T(\mathrm{sec})}$

Where $U$ is the curdling potential of enzyme in soxhlet, $M$ is refers to milk, $E$ is amount of phase sample, $t$ is the temperature of substrate enzyme reaction and $T$ is the clotting time in seconds. All the values were determined in triplicates.

\section{Results and Discussion}

\subsection{Confirmation of bacteria for protease production}

In the present study, the isolated bacteria identified as Bacillus sp. was characterized for protease production on skim milk agar plates [28]. The clear zones produced around the wells in skim milk agar plate depicted that casein has been hydrolyzed and the bacteria have extracellular protease activity. It was observed (Fig. 1A) that by using different amount of supernatant 10, 15, 20, 25 and $30 \mu \mathrm{L}$ in each well the diameter of zone increased 15,17 , 19,20 and $21 \mathrm{~mm}$, respectively, reflecting that by increasing the amount of supernatant the activity of protease increased subsequently in each well. The activity of the enzyme at different volumes is also explained in Fig. 1B.

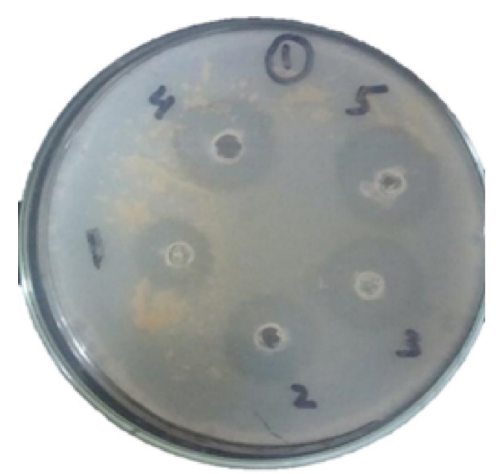

A

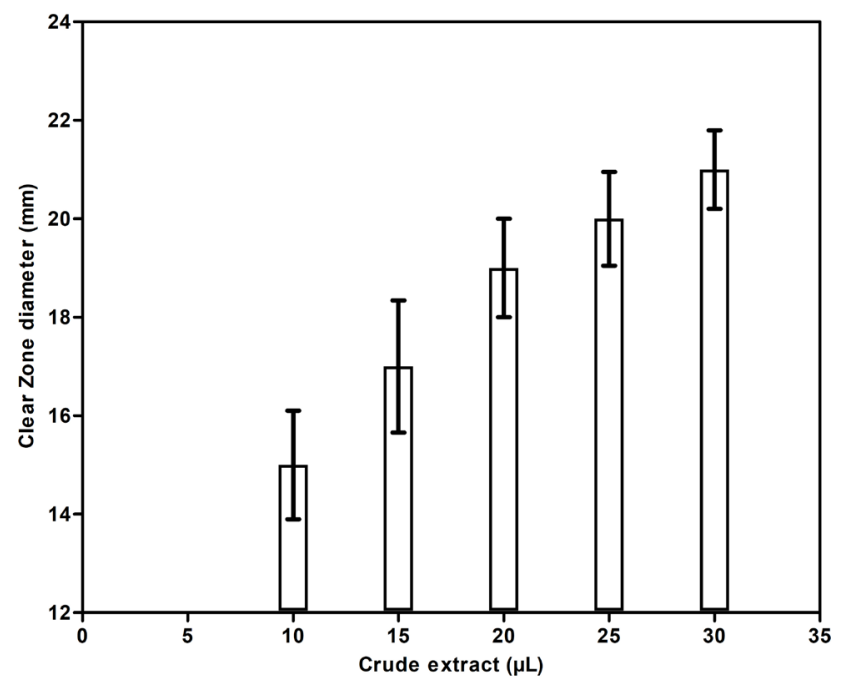

B

Fig. 1 A) Protease assay performed for different volumes (10, 15, 20, 25 and $30 \mu \mathrm{L}$ ) of supernatant on skimmed milk agar plate; B) Bar graph determining the activity of different volumes $(10,15,20,25$ and $30 \mu \mathrm{L})$ of the supernatant

\subsection{Effect of phase forming salt (ammonium sulphate) concentration on partitioning of protease}

This study was carried out to investigate the effect of phase forming salt and their concentration on the partition behavior of proteases. Increasing salt concentration increases the partition coefficients of bio-product to top phase or interface due to salting out effect [31,32].

Generally, in PEG/salt systems protein with positive charge generally move to the bottom phase while negatively charged proteins tend to move to the top phase $[33,34]$. The partition behavior of our protease was studied using several compositions of PEG (4000, 6000 and 10000) i.e., 15, 17.5 and $20 \%$ with different $\left(\mathrm{NH}_{4}\right)_{2} \mathrm{SO}_{4}$ concentrations. In general, no phase separation was observed in the presence of either salt or PEG alone. This shows that for phase separation the combination of both PEG and salt is necessary. 
The results did not show phase separation at $17.5 \%$ PEG 4000 and $7.5 \%\left(\mathrm{NH}_{4}\right)_{2} \mathrm{SO}_{4}$ as stated in Table 1 . The possible reason is the insufficient quantity of the salt required for the phase separation. Phase formation refers to the formation of two different phases while no phase separation is actually the condition in which the applied supernatant stays at the interface of the two phases.

As depicted by the Table 1 that increasing the salt concentration the protease predominantly move to the top phase (rich in PEG), which increases activity (Soxhlet unit) and partition coefficient. At high salt concentration the solubility of protein decreases because of salting out effect and move to the top phase. Cavalcanti et al. [35] reported that increase in salt concentration on negatively charged protein prefer to move the top phase (rich in PEG) because of repulsive force caused by salt anions.

From the results, the highest partition coefficient (3.32) was found in the system of $20 \%$ PEG 4000 and $9.9 \%$ $\left(\mathrm{NH}_{4}\right)_{2} \mathrm{SO}_{4}$ (Fig. 2B). The effect of increasing salt concentration in case of PEG 4000, 6000 and 10000, performed in triplicate, are shown in Fig. 2, 3 and 4, respectively.

Similar results were found [34] for the extraction of uricase from Candida subtilis by applying PEG/ $\left(\mathrm{NH}_{4}\right)_{2} \mathrm{SO}_{4}$ system. These authors reported that increasing the concentration of $\left(\mathrm{NH}_{4}\right)_{2} \mathrm{SO}_{4}$ the salting out effect was increased and uricase moved to the top phase. Similar outcomes were reported for the purification of a thermostable xylanase [36] using ATPS of PEG/( $\left.\mathrm{NH}_{4}\right)_{2} \mathrm{SO} 4$.
Their results showed that elevated salt $\left(\left(\mathrm{NH}_{4}\right)_{2} \mathrm{SO} 4\right)$ concentration increased the partition coefficient.

\subsection{Effect of PEG concentration on partitioning of protease}

The effect of PEG (4000, 6000 and 10000) concentrations $(15,17.5$ and $20 \%)$ on protease partitioning at a constant ammonium sulphate concentration were studied.

Results showed that increasing the concentration of PEG 4000 and PEG 6000, an increase in the activity (Soxhlet units) and partition coefficient of protease was observed in the top phase. For example, in Table 1, in case of PEG 4000, the units in top phase increased from 11.00 (T6) to 13.76 (T10), by increasing the concentration of PEG 4000 from $17.5 \%$ to $20 \%$ (keeping the salt concentration constant). In the same case, the partition co-efficient increased from 1.24 to 2.05. In case of PEG 6000, the number of units in the top phase increased from 9.33 (T1) to 11.20 (T5) by increasing the concentration of PEG from 15 to $17.5 \%$. Considering the same runs the partition co-efficient increased from 0.90 to 1.64 . The same trend was observed when the concentration of PEG 6000 increased from $17.5 \%$ to $20 \%$. Increasing the concentration of PEG improves the hydrophobic interaction between surface of protein and PEG [37].

Similar partitioning behavior of protease (bromelain) from pineapple peel were reported [38] in ATPS containing different molecular weight (2000, 4000 and 6000) and

Table 1 Effect of concentration of PEG 4000, PEG 6000 and PEG 10000 and phase forming salt $\left(\left(\mathrm{NH}_{4}\right)_{2} \mathrm{SO}_{4}\right)$ on the partition coefficient of protease

\begin{tabular}{|c|c|c|c|c|c|c|c|c|c|c|c|c|}
\hline \multirow[t]{2}{*}{ Run } & \multicolumn{4}{|c|}{ PEG 4000} & \multicolumn{4}{|c|}{ PEG 6000} & \multicolumn{4}{|c|}{ PEG 10000} \\
\hline & $\begin{array}{c}\text { \%PEG: } \\
\% \mathrm{AS}\end{array}$ & $\begin{array}{l}\text { Top phase } \\
(\mathrm{U} / \mathrm{mL})\end{array}$ & $\begin{array}{c}\text { Bottom } \\
\text { phase } \\
(\mathrm{U} / \mathrm{mL})\end{array}$ & $\begin{array}{c}\text { Partition } \\
\text { coefficient }\end{array}$ & $\begin{array}{l}\text { \%PEG: } \\
\% \mathrm{AS}\end{array}$ & $\begin{array}{l}\text { Top phase } \\
(\mathrm{U} / \mathrm{mL})\end{array}$ & $\begin{array}{l}\text { Bottom } \\
\text { phase } \\
(\mathrm{U} / \mathrm{mL})\end{array}$ & $\begin{array}{l}\text { Partition } \\
\text { coefficient }\end{array}$ & $\begin{array}{c}\% \text { PEG: } \\
\% \text { AS }\end{array}$ & $\begin{array}{l}\text { Top phase } \\
(\mathrm{U} / \mathrm{mL})\end{array}$ & $\begin{array}{c}\text { Bottom } \\
\text { phase } \\
(\mathrm{U} / \mathrm{mL})\end{array}$ & $\begin{array}{c}\text { Partition } \\
\text { coefficient }\end{array}$ \\
\hline $\mathrm{T} 1$ & $15: 7.5$ & \multirow{4}{*}{\multicolumn{3}{|c|}{$\begin{array}{c}\text { NO PHASE FORM } \\
15: 8.3 \\
9.36 \\
15: 9.1 \\
11.60 \\
15: 9.9 \\
12.06\end{array}$}} & $15: 7.5$ & 9.33 & 10.33 & 0.90 & $15: 7.5$ & 6.70 & 9.66 & 0.69 \\
\hline $\mathrm{T} 2$ & $15: 8.3$ & & & & 10.33 & 0.90 & $15: 8.3$ & 7.00 & 9.03 & 0.77 & & \\
\hline T3 & 15: 9.1 & & & & 8.70 & 1.33 & 15: 9.1 & 7.30 & 8.83 & 0.82 & & \\
\hline $\mathrm{T} 4$ & 15: 9.9 & & & & 8.33 & 1.44 & 15: 9.9 & 7.43 & 8.66 & 0.85 & & \\
\hline $\mathrm{T} 5$ & 17.5: 7.5 & NS & NS & NS & $17.5: 7.5$ & 11.20 & 9.36 & 1.19 & $17.5: 7.5$ & 7.00 & 8.83 & 0.79 \\
\hline T6 & $17.5: 8.3$ & 11.00 & 8.86 & 1.24 & $17.5: 8.3$ & 11.70 & 9.20 & 1.27 & $17.5: 8.3$ & 7.50 & 8.60 & 0.87 \\
\hline $\mathrm{T} 7$ & 17.5: 9.1 & 14.13 & 5.70 & 2.47 & 17.5: 9.1 & 13.86 & 6.70 & 2.06 & 17.5: 9.1 & 8.10 & 7.93 & 1.02 \\
\hline $\mathrm{T} 8$ & 17.5: 9.9 & 15.66 & 5.06 & 3.09 & 17.5: 9.9 & 15.30 & 6.00 & 2.55 & 17.5: 9.9 & 9.93 & 6.90 & 1.43 \\
\hline T9 & $20: 7.5$ & 9.40 & 10.60 & 0.88 & 20: 7.5 & 13.16 & 8.00 & 1.64 & $20: 7.5$ & 5.54 & 9.83 & 0.56 \\
\hline $\mathrm{T} 10$ & $20: 8.3$ & 13.76 & 6.70 & 2.05 & $20: 8.3$ & 13.50 & 7.50 & 1.88 & $20: 8.3$ & 6.40 & 9.46 & 0.67 \\
\hline $\mathrm{T} 11$ & $20: 9.1$ & 14.90 & 5.10 & 2.92 & 20: 9.1 & 14.50 & 6.50 & 2.23 & 20: 9.1 & 7.16 & 8.90 & 0.80 \\
\hline $\mathrm{T} 12$ & $20: 9.9$ & 16.06 & 4.83 & 3.32 & 20: 9.9 & 15.50 & 5.50 & 2.81 & 20: 9.9 & 7.20 & 8.80 & 0.82 \\
\hline
\end{tabular}

NS; No separation. AS; ammonium sulphate 

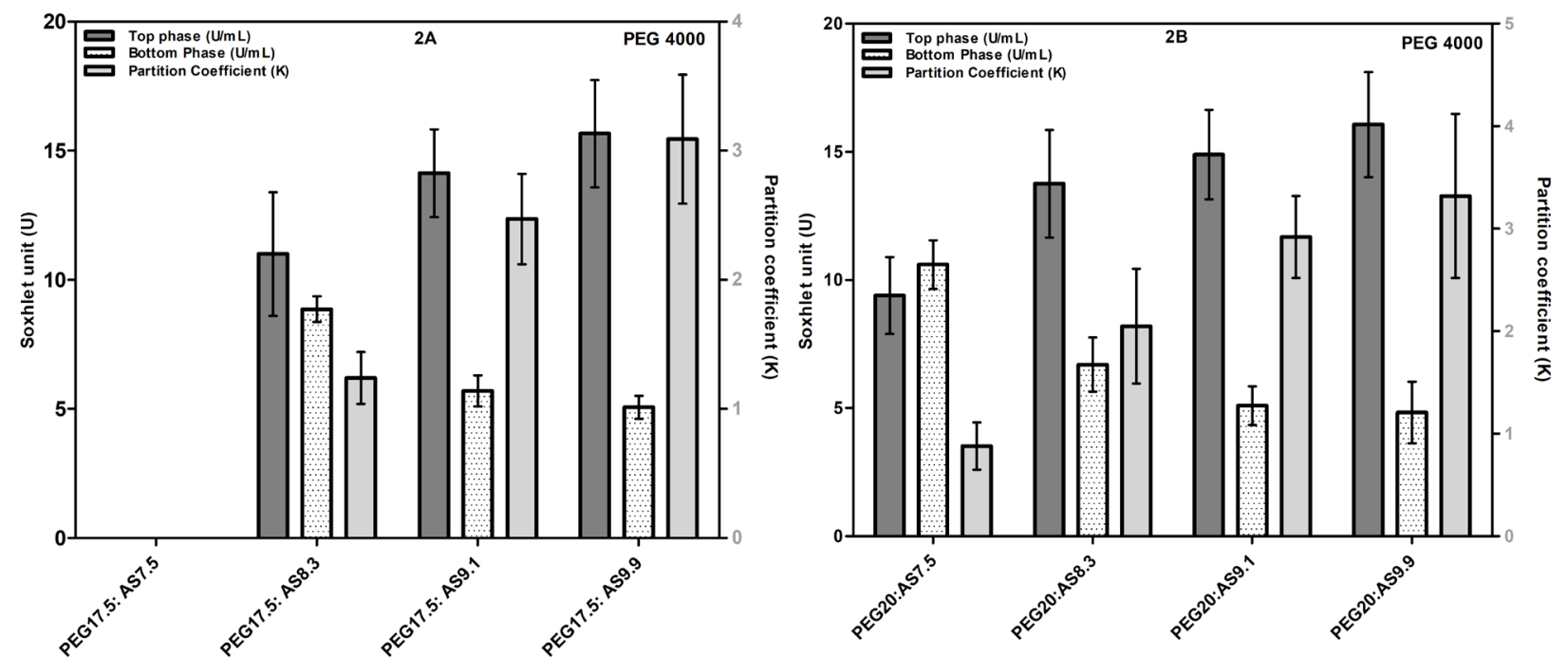

Fig. 2 The effect of increasing salt concentration on the soxhlet unit and partition coefficient in phases, the PEG 4000 concentration is kept constant that is $17.5 \%(\mathrm{~A})$ and $20 \%(\mathrm{~B})$

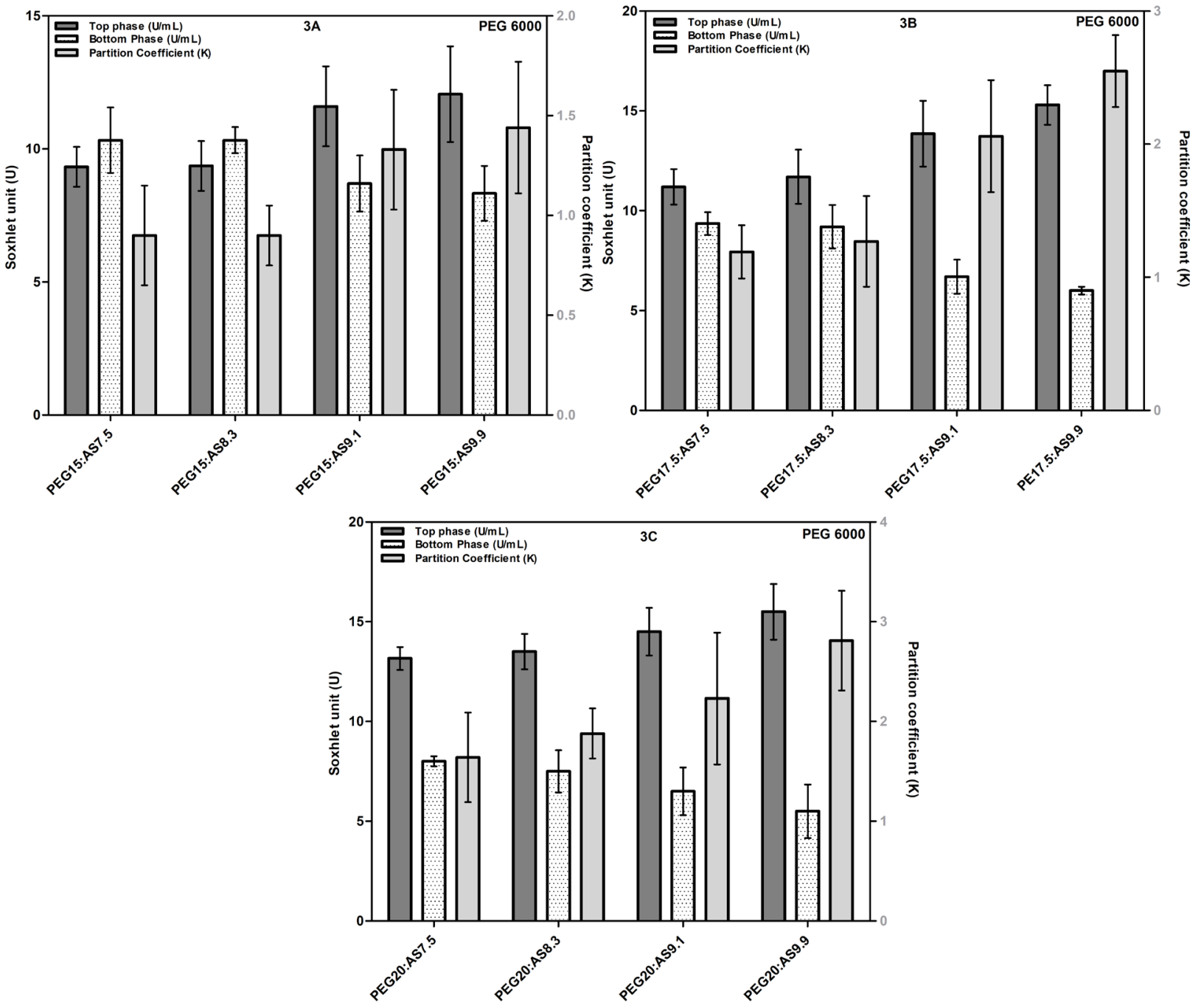

Fig. 3 The effect of increasing salt concentration on the soxhlet unit and partition coefficient in phases, the PEG 6000 concentration is kept constant that is $15 \%(\mathrm{~A}), 17.5 \%(\mathrm{~B})$ and $20 \%(\mathrm{C})$. 


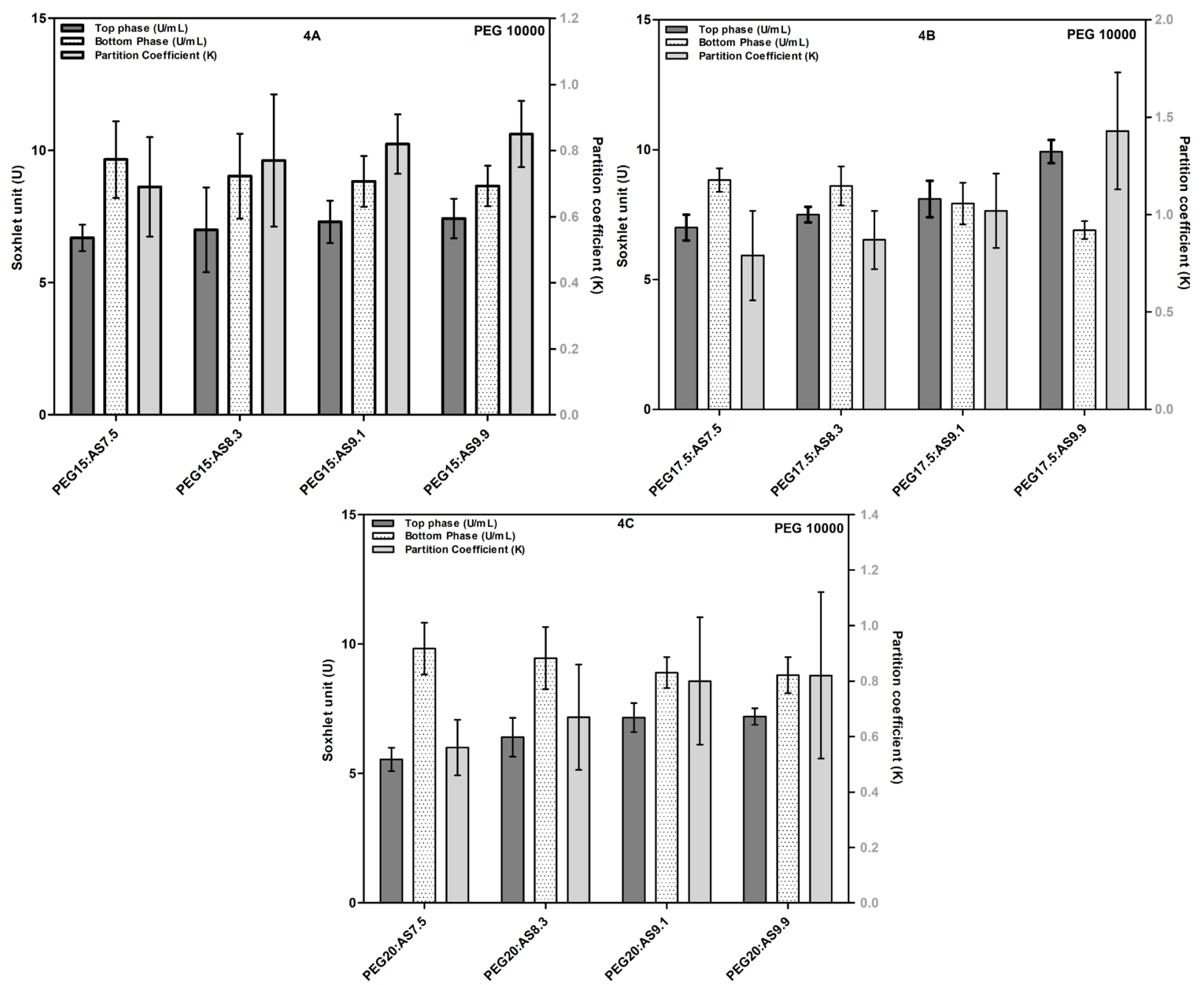

Fig. 4 The effect of increasing salt concentration on the soxhlet unit and partition coefficient in phases, the PEG 10000 concentration is kept constant that is $15 \%(\mathrm{~A}), 17.5 \%(\mathrm{~B})$ and $20 \%(\mathrm{C})$.

concentrations of PEG (12, 15 and $18 \%)$ with constant concentration of $\mathrm{MgSO}_{4}(17 \%)$. An opposite behavior was observed for PEG 10000. Increasing the concentration of PEG 10000 from 17.5 to $20 \%$ (T5 and T9), the partition coefficient of protease slightly decreased (from 0.79 to 0.56 ).

This would be explained according to the partitioning theory that high PEG concentration in the system increases the viscosity and interfacial tension between the phases. Thus the movement of protease to the upper phase is retarded resulting in decreased partition coefficient [39], These studies are time indepedant.

\subsection{Effect of PEG molecular weight on partitioning of protease}

The extraction efficiency of the ATPS decreases by increasing the molecular weight of PEG. At high molecular weight of the PEG, the interaction between PEG and protein domain decreases. This is due to high viscosity of PEG. At high molecular weight PEG the exclusion effect increases and as a result the polymer excluded the protein to the lower phase. Yet, there is no common rule about the mechanism governing the partition [40]. In order to find out the most suitable molecular weight of PEG for the partial recovery of protease, partitioning studies were carried out by using various $\mathrm{PEG} /\left(\mathrm{NH}_{4}\right)_{2} \mathrm{SO}_{4}$ systems with different molecular weight of PEG (4000, 6000 and 10,000). The partition coefficient of protease was found to be decreased with increase of molecular weight of PEG (Table 1). The decrease in the partition coefficient of protease could be attributed to the effect of volume exclusion, which increases with an increase in molecular weight of PEG. As a result, the biomolecules will selectively move to the bottom phase. Similar interrelationship was also found by [41] by using PEG-phosphate systems 
with PEG molecular weight 600 to 20,000. Similar results were observed by [42-45].

\section{Conclusions}

Aqueous two phase system composed of PEG/( $\left.\mathrm{NH}_{4}\right)_{2} \mathrm{SO}_{4}$ proved to be potentially useful for the extraction of protease from bacterial source. The isolation and purification of protease from bacterial source was studied under different concentrations of PEG molecular weight (4000, 6000 and 10000) with different concentrations of $\left(\mathrm{NH}_{4}\right)_{2} \mathrm{SO}_{4}$. It was indicated that molecular weight, concentration of PEG and $\left(\mathrm{NH}_{4}\right)_{2} \mathrm{SO}_{4}$ had a prominent effect on the partitioning of protease. It can be concluded from the experimental results that in $\mathrm{PEG} /\left(\mathrm{NH}_{4}\right)_{2} \mathrm{SO}_{4}$ system, low molecular

\section{References}

[1] Deng, A., Wu, J., Zhang, Y., Zhang, G., Wen, T. "Purification and characterization of a surfactant-stable high-alkaline protease from Bacillus sp. B001", Bioresource Technology, 101(18), pp. 7100-7106, 2010. https://doi.org/10.1016/j.biortech.2010.03.130

[2] Gaur, S., Agrahari, S., Wadhwa, N. "Purification of Protease from Pseudomonas thermaerum GW1 Isolated from Poultry Waste Site", The Open Microbiology Journal, 4, pp. 67-74, 2010. https://doi.org/10.2174/1874285801004010067

[3] Dubey, V. K., Pande, M., Singh, B. K., Jagannadham, M. V. "Papain-like proteases: Applications of their inhibitors", African Journal of Biotechnology, 6(9), pp. 1077-1086, 2007.

[4] Zhao, L., Budge, S. M., Ghaly, A. E., Brooks, M. S., Dave, D. "Extraction, Purification and Characterization of Fish Pepsin: A Critical Review", Journal of Food Processing \& Technology, 2(6), pp. 1000126, 2011.

https://doi.org/10.4172/2157-7110.1000126

[5] Wilson, P., Remigio, Z. "Production and characterisation of protease enzyme produced by a novel moderate thermophilic bacterium (EP1001) isolated from an alkaline hot spring, Zimbabwe", African Journal of Microbiology Research, 6(27), pp. 5542-5551, 2012. https://doi.org/10.5897/ajmr11.158

[6] Jozala, A. F., Geraldes, D. C., Tundisi, L. L., Feitosa, V. D. A., Breyer, C. A., Cardoso, S. L., Mazzola, P. G., de OliveiraNascimento, L., de Oliveira Rangel-Yagui, C., de Oliveira Magalhães, P., de Oliveira, M. A., Pessoa, A. "Biopharmaceuticals from microorganisms: from production to purification", Brazilian Journal of Microbiology, 47(1), pp. 51-63, 2016. https://doi.org/10.1016/j.bjm.2016.10.007

[7] Sameera, V. "Novel Techniques in the Production of Industrially Imperative Products", Jornal of Microbial \& Biochemical Technology, R1, 2011.

https://doi.org/10.4172/1948-5948.r1-003

[8] Akpor, O., Muchie, M. "Remediation of heavy metals in drinking water and wastewater treatment systems: Processes and applications", International Journal of Physical Sciences, 5(12), pp. 1807$1817,2010$. weight PEG (4000) was beneficial for partitioning of protease, when compared to other PEG (6000 and 10000) systems. A maximum partition coefficient 3.32, was obtained with a system of PEG $4000(20 \%)$ and $\left(\mathrm{NH}_{4}\right)_{2} \mathrm{SO}_{4}(9.9 \%)$. All study systems demonstrate that increasing salt concentration had positive effect on the partitioning of protease, which suggested that partition coefficient of protease could be further improved by increasing the salt concentration

\section{Acknowledgements}

The authors are thankful to Directorate of Science and Technology, Khyber Pakhtunkhwa, Pakistan for the financial support.

[9] Saraswat, M., Musante, L., Ravidá, A., Shortt, B., Byrne, B., Holthofer, H. "Preparative Purification of Recombinant Proteins: Current Status and Future Trends", BioMed Research International, 2013, Article ID 312709, 2013. https://doi.org/10.1155/2013/312709

[10] Raja, S., Murty, V. R., Thivaharan, V., Rajasekar, V., Ramesh, V. "Aqueous Two Phase Systems for the Recovery of Biomolecules A Review", Science and Technology, 1(1), pp. 7-16, 2011. https://doi.org/10.5923/j.scit.20110101.02

[11] Naganagouda, K., Mulimani, V. H. "Aqueous two-phase extraction (ATPE): An attractive and economically viable technology for downstream processing of Aspergillus oryzae $\alpha$-galactosidase", Process Biochemistry, 43(11), pp. 1293-1299, 2008. https://doi.org/10.1016/j.procbio.2008.07.016

[12] Deng, Y., Long, T., Zhang, D., Chen, J., Gan, S. "Phase Diagram of $[$ Amim $] \mathrm{Cl}+$ Salt Aqueous Biphasic Systems and Its Application for [Amim]Cl Recovery", Journal of Chemical \& Engineering Data, 54(9), pp. 2470-2473, 2009. https://doi.org/10.1021/je900009a

[13] Teixeira, A. G., Agarwal, R., Ko, K. R., Grant-Burt, J., Leung, B. M., Frampton, J. P. "Emerging Biotechnology Applications of Aqueous Two-Phase Systems", Advanced Healthcare Materials, 7(6), pp. 1701036, 2018.

https://doi.org/10.1002/adhm.201701036

[14] Suarez Ruiz, C. A., van den Berg, C., Wijffels, R. H., Eppink, M. H. M. "Rubisco separation using biocompatible aqueous two-phase systems", Separation and Purification Technology, 196, pp. 254-261, 2018.

https://doi.org/10.1016/j.seppur.2017.05.001

[15] Iqbal, M., Tao, Y., Xie, S., Zhu, Y., Chen, D., Wang, X., Huang, L., Peng, D., Sattar, A., Shabbir, M. A. B., Hussain, H. I., Saed, A., Yuan, Z. "Aqueous two-phase system (ATPS): an overview and advances in its applications", Biological Procedures Online, 18, pp. 1-18, 2016. https://doi.org/10.1186/s12575-016-0048-8 
[16] Bridges, N. J., Gutowski, K. E., Rogers, R. D. "Investigation of aqueous biphasic systems formed from solutions of chaotropic salts with kosmotropic salts (salt-salt ABS)", Green Chemistry, 9(2), pp. 177-183, 2007. https://doi.org/10.1039/b611628k

[17] Lladosa, E., Silvério, S. C., Rodríguez, O., Teixeira, J. A., Macedo, E. A. "(Liquid+ liquid) equilibria of polymer-salt aqueous two-phase systems for laccase partitioning: UCON 50-HB5100 with potassium citrate and (sodium or potassium) formate at $23{ }^{\circ} \mathrm{C}$ ", The Journal of Chemical Thermodynamics, 55, pp. 166$171,2012$. https://doi.org/10.1016/j.jpt.2012.06.002

[18] Lee, S. Y., Khoiroh, I., Ooi, C. W., Ling, T. C., Show, P. L. "Recent Advances in Protein Extraction Using Ionic Liquid-based Aqueous Two-phase Systems", Separation \& Purification Reviews, 46(4), pp. 291-304, 2017. https://doi.org/10.1080/15422119.2017.1279628

[19] Chen, X., Xu, G., Li, X., Li, Z., Ying, H. "Purification of an $\alpha$-amylase inhibitor in a polyethylene glycol/fructose-1,6bisphosphate trisodium salt aqueous two-phase system", Process Biochemistry, 43(7), pp. 765-768, 2008. https://doi.org/10.1016/j.procbio.2008.03.003

[20] Molino, J. V. D., Lopes, A. M., de Araújo Viana Marques, D., Mazzola, P. G., da Silva, J. L., Hirata, M. H., Hirata, R. D. C., Gatti, M. S. V., Pessoa, A. "Application of aqueous two-phase micellar system to improve extraction of adenoviral particles from cell lysate", Biotechnology and Applied Biochemistry, 65(3), pp. 381-389, 2018. https://doi.org/10.1002/bab.1627

[21] Ashipala, O. K., He, Q. "Optimization of fibrinolytic enzyme production by Bacillus subtilis DC-2 in aqueous two-phase system (poly-ethylene glycol 4000 and sodium sulfate)", Bioresource Technology, 99(10), pp. 4112-4119, 2008. https://doi.org/10.1016/j.biortech.2007.09.029

[22] Samatou, J. A., Engbert Wentink, A., Rosa, P. A. J., Azevedo, A. M., Aires-Barros, M. R., Bäcker, W., Górak A. "Modeling of counter current monoclonal antibody extraction using aqueous two-phase systems", Computer Aided Chemical Engineering, 24, pp. 935-940, 2007. https://doi.org/10.1016/s1570-7946(07)80180-5

[23] Bora, M. M., Borthakur, S., Rao, P. C., Dutta, N. N. "Aqueous twophase partitioning of cephalosporin antibiotics: effect of solute chemical nature", Separation and Purification Technology, 45(2), pp. 153-156, 2005. https://doi.org/10.1016/j.seppur.2004.08.006

[24] Nitsawang, S., Hatti-Kaul, R., Kanasawud, P. "Purification of papain from Carica papaya latex: Aqueous two-phase extraction versus two-step salt precipitation", Enzyme and Microbial Technology, 39(5), pp. 1103-1107, 2006. https://doi.org/10.1016/j.enzmictec.2006.02.013

[25] Haddar, A., Etis, N., Nasri, M. "Novel complex organic substrates for cultivation of bacteria like Bacillus mojavensis A21", African Journal of Microbiology Research, 6(47), pp. 7377-7382, 2012. https://doi.org/10.5897/ajmr12.243
[26] Gupta, R., Beg, Q., Khan, S., Chauhan, B. "An overview on fermentation, downstream processing and properties of microbial alkaline proteases", Applied Microbiology and Biotechnology, 60(4), pp. 381-395, 2002. https://doi.org/10.1007/s00253-002-1142-1

[27] Swamy, M. K., Kashyap, S. S. N., Vijay, R., Tiwari, R., Anuradha, M. "Production and optimization of extra cellular protease from Bacillus sp. isolated from soil", International Journal of Biological Sciences, 3(2), pp. 564-569, 2012.

[28] Chantawannakul, P., Oncharoen, A., Klanbut, K., Chukeatirote, E., Lumyong, S. "Characterization of proteases of Bacillus subtilis strain 38 isolated from traditionally fermented soybean in Northern Thailand", ScienceAsia, 28, pp. 241-245, 2002. https://doi.org/10.2306/scienceasia1513-1874.2002.28.241

[29] Hatti-Kaul, R. "Aqueous two-phase systems", Molecular Biotechnology, 19(3), pp. 269-277, 2001. https://doi.org/10.1385/MB:19:3:269

[30] Arima, K., Yu, J., Iwasaki, S. "[30] Milk-clotting enzyme from Mucor pusillus var. Lindt", Methods in Enzymology, 19, pp. 446-459, 1970. https://doi.org/10.1016/0076-6879(70)19033-1

[31] Hemavathi, A. B., Raghavarao, K. S. M. S. "Differential partitioning of $\beta$-galactosidase and $\beta$-glucosidase using aqueous two phase extraction", Process Biochemistry, 46(3), pp. 649-655, 2011. https://doi.org/10.1016/j.procbio.2010.11.008

[32g Yücekan, İ., Önal, S. "Partitioning of invertase from tomato in poly(ethylene glycol)/sodium sulfate aqueous two-phase systems", Process Biochemistry, 46(1), pp. 226-232, 2011. https://doi.org/10.1016/j.procbio.2010.08.015

[33] Karkaş, T., Önal, S. "Characteristics of invertase partitioned in poly(ethylene glycol)/magnesium sulfate aqueous two-phase system", Biochemical Engineering Journal, 60, pp. 142-150, 2012. https://doi.org/10.1016/j.bej.2011.11.005

[34] Chen, Y., Meng, Y.-F., Tang, J.-B., Sun, T.-Y., Sun, F.-X., Liang, S.-J. "Extraction of uricase from Candida utilis by applying polyethylene glycol (PEG)/NH4)2SO4 aqueous two-phase system", African Journal of Biotechnology, 9(30), pp. 4788-4795, 2010.

[35] Cavalcanti, M. T. H., Porto, T. S., de Barros Neto, B., LimaFilho, J. L., Porto, A. L. F., Pessoa Jr, A. "Aqueous two-phase systems extraction of $\alpha$-toxin from Clostridium perfringens type A", Journal of Chromatography B, 833(2), pp. 135-140, 2006. https://doi.org/10.1016/j.jchromb.2006.01.023

[36] Yang, S., Huang, Z., Jiang, Z., Li, L. "Partition and purification of a thermostable xylanase produced by Paecilomyces thermophila in solid-state fermentation using aqueous two-phase systems", Process Biochemistry, 43(1), pp. 56-61, 2008. https://doi.org/10.1016/j.procbio.2007.10.013

[37] Bassani, G., Farruggia, B., Nerli, B., Romanini, D., Picó, G. "Porcine pancreatic lipase partition in potassium phosphatepolyethylene glycol aqueous two-phase systems", Journal of Chromatography B, 859(2), pp. 222-228, 2007. https://doi.org/10.1016/j.jchromb.2007.09.038

[38] Ketnawa, S., Rawdkuen, S., Chaiwut, P. "Two phase partitioning and collagen hydrolysis of bromelain from pineapple peel Nang Lae cultivar", Biochemical Engineering Journal, 52(2-3), pp. 205211, 2010.

https://doi.org/10.1016/j.bej.2010.08.012 
[39] Ratanapongleka, K. "Partitioning behavior of laccase from Lentinus polychrous Lev in aqueous two phase systems", Songklanakarin Journal of Science \& Technology, 34(1), pp. 69-76, 2012.

[40] Guo-qing, H., Xiu-yan, Z., Xing-jun, T., Qi-he, C., Hui, R. "Partitioning and purification of extracellular $\beta-1,3-1,4$-glucanase in aqueous two-phase systems", Journal of Zhejiang University Science B, 6(8), pp. 825-831, 2005. https://doi.org/10.1631/jzus.2005.b0825

[41] Lahore, H. M. F., Miranda, M. V., Fraile, E. R., de Jiménez Bonino, M. J. B., Cascone, O. "Partition behaviour and purification of a Mucor bacilliformis acid protease in aqueous two-phase systems", Process Biochemistry, 30(7), pp. 615-621, 1995. https://doi.org/10.1016/0032-9592(94)00026-3

[42] Nandini, K. E., Rastogi, N. K. "Liquid-Liquid Extraction of Lipase Using Aqueous Two-Phase System", Food and Bioprocess Technology, 4(2), pp. 295-303, 2011.

https://doi.org/10.1007/s11947-008-0160-0
[43] Mehrnoush, A., Sarker, Md. Z. I., Mustafa, S., Yazid, A. M. M. "Direct Purification of Pectinase from Mango (Mangifera Indica cv. Chokanan) Peel Using a PEG/Salt-Based Aqueous Two Phase System", Molecules, 16(10), pp. 8419-8427, 2011. https://doi.org/10.3390/molecules16108419

[44] Lakshmi, M. C., Madhusudhan, M., Raghavarao, K. S. M. S. "Extraction and Purification of Lipoxygenase from Soybean Using Aqueous Two-Phase System", Food and Bioprocess Technology, 5(1), pp. 193-199, 2012. https://doi.org/10.1007/s11947-009-0278-8

[45] Ramesh, V., Murty, V. R. "Partitioning of thermostable glucoamylase in polyethyleneglycol/salt aqueous two-phase system", Bioresources and Bioprocessing, 2(1), pp. 25, 2015. https://doi.org/10.1186/s40643-015-0056-6 